\title{
Molecular and Clinical Characteristics of 26 Cases with Structural Y Chromosome Aberrations
}

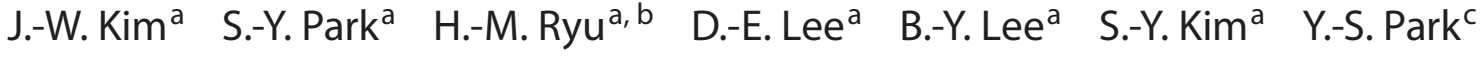 \\ H.-S. Lee ${ }^{c}$ J.-T. Seo ${ }^{d}$ \\ a Laboratory of Medical Genetics, ${ }^{b}$ Department of Obstetrics and Gynecology, ' Laboratory of Reproductive Biology \\ and Infertility, and dDepartment of Urology, Cheil General Hospital and Women's Healthcare Center, Kwandong \\ University School of Medicine, Seoul, Korea
}

\section{Key Words}

AZF region microdeletions $\cdot$ Infertility $\cdot$ Structural $Y$ chromosome aberrations

\begin{abstract}
Structural abnormalities include various types of translocations, inversions, deletions, duplications and isochromosomes. Structural abnormalities of the $Y$ chromosome are estimated to affect less than $1 \%$ of the newborn male population and are particularly hazardous for male reproductive function. The objective of this study was to characterize a group of patients with structural abnormalities of the Y chromosome. All patients who visited our laboratory between 2007 and 2010 underwent cytogenetic investigations. Among these, we detected 26 patients with structural abnormalities of the $Y$ chromosome. To confirm the structural $Y$ chromosome alterations, we used special bandings, FISH and multiplex PCR to detect $Y$ chromosome microdeletions. Of the 26 patients presented here, 11 had an isodicentric $Y$ chromosome, 7 had an inversion, 3 had a translocation, 2 had a derivative, 2 had a Yqs and 1 had a deletion. Sixteen were diagnosed with azoospermia, 8 as normal fertile males and 1 as a man who was unable to donate semen due to mental retardation. One of the patients having $45, \mathrm{X} / 46, \mathrm{X}, \operatorname{idic}(\mathrm{Y})$ was
\end{abstract}

reported to be phenotypically female with primary amenorrhea and without uterus. Deletions of the AZFbc region were correlated with the sperm concentration $(p<0.05)$, but no correlation with the levels of $\mathrm{FSH}$, $\mathrm{LH}$, testosterone, prolactin and estradiol were found. The present report shows that the precise identification of structural $Y$ chromosome aberrations may be clinically important for genetic counseling and assisted reproductive technology treatment.

Copyright $\odot 2012$ S. Karger AG, Base

The human Y chromosome is one of the smallest human chromosomes, consisting of a short (Yp) and a long (Yq) arm. The Y chromosome is $60 \mathrm{Mb}$ in size but has the smallest number of genes compared to all other chromosomes. Of the $27 \mathrm{Y}$ chromosome genes identified, 9 are located on Yp and the remaining 18 on Yq [Skaletsky et al., 2003]. The genes on the $Y$ chromosome are essential for male sex determination, early sexual differentiation and control of spermatogenesis [Disteche et al., 1986; Arnemann et al., 1991; Gardner and Sutherland, 1996].

Structural abnormalities occur because of breakage and rejoining of a chromosome and include various types of translocations, deletions, ring chromosomes, duplica-

\section{KARGER}

Fax +4161306 1234

E-Mail karger@karger.ch

www.karger.com
(C) 2012 S. Karger AG, Basel

$1424-8581 / 12 / 1364-0270 \$ 38.00 / 0$

Accessible online at:

www.karger.com/cgr
Ju-Tae Seo

Department of Urology

Cheil General Hospital and Women's Healthcare Center

1-19 Mukjeong-dong, Jung-Gu, Seoul 100-380 (Korea)

Tel. +82 22000 7585, E-Mail jtandro@cgh.co.kr 
tions, inversions and isochromosomes. There are 2 types of structural aberrations: balanced structural aberrations, such as translocations or inversions, with a normal complement of chromosomal material, and unbalanced structural aberrations, such as deletions, duplications or isochromosomes, with loss or gain of chromosomal material. Structural anomalies of the Y chromosome are particularly hazardous for male reproductive function [Sinclair et al., 1990]. Ring chromosomes and isochromosomes of both short and long arms are the most prevalent causes of spermatogenic failure and azoospermia [Lin et al., 2005; DesGroseilliers et al., 2006].

The azoospermia factor (AZF) region maps within intervals 5 and 6 of the $Y$ chromosome and contains many genes involved in the growth and development of sperm, such as the USP9Y, RBMY1, BPY2 and DAZ genes [Vogt et al., 1996]. The AZF region is further subdivided into 3 regions defined as AZFa, AZFb and AZFc. A microdeletion in the AZF region is defined as a chromosomal deletion that spans several genes but is not large enough to be detected using conventional cytogenetic methods. Such microdeletions have been implicated in the pathogenesis of spermatogenic failure. The prevalence of microdeletions was found to range between 10 and $15 \%$ in azoospermia and 5 and $10 \%$ in severe oligozoospermia. However, such observations have not identified any particular Y-chromosome-encoded protein associated with spermatogenic function because each of these deletions removes multiple genes.

In this study, we characterized structural abnormalities in the $\mathrm{Y}$ chromosome of 26 patients analyzed at the cytogenetic, molecular and clinical levels at our center during a 4-year period.

\section{Materials and Methods}

\section{Patients}

This study was approved by the institutional ethics committee of Cheil General Hospital and included 26 patients with structural abnormalities of the $\mathrm{Y}$ chromosome who were examined in our clinic between January 2007 and December 2010. These patients included 15 men with primary infertility who attended the Department of Urology, 3 men with Y chromosomal abnormalities confirmed by other hospitals, 5 men with paternal testing for $\mathrm{Y}$ chromosome aberration in amniocytes, 2 men whose partners experienced recurrent abortion and 1 woman with short height $(146 \mathrm{~cm})$ and primary amenorrhea. The mean age of the patients was 34.9 years (range: $23-47$ ).

Cytogenetic and FISH Analysis

Metaphase chromosome preparations from peripheral blood lymphocytes were obtained using standard procedures and stained using standard GTL- and RBG-banding techniques. The karyotype description followed the International System for $\mathrm{Hu}-$ man Cytogenetic Nomenclature [ISCN 2005, 2009]. At least 50 metaphases were analyzed for each patient and up to 100 metaphases in cases of mosaicism. Special techniques such as CBG-, DA-DAPI- and NOR-staining were additionally applied. FISH was carried out with multiple probes for the Y chromosome, including SRY (LSI SRY SO/CEP X SG, Vysis, Downers Grove, Ill., USA), Yq12 heterochromatin/Y centromeric region (CEP Y Sat III SG/CEP Y alpha SO, Vysis) and 22q telomeric region (TelVysion $22 \mathrm{q} \mathrm{SO}$, Vysis). For each analysis, a minimum of 10 metaphase and 100 interphase cells were scored.

\section{Y Chromosome Microdeletion Analysis}

Microdeletion analysis of the AZF region was performed by multiplex PCR using 16 sequence-tagged sites. The sequencetagged site primers used were sY14 (SRY); sY84, sY86 (AZFa); sY124, sY127, sY129, sY130, sY134 (AZFb); sY147, sY242, sY254, sY255, SPGY1, sY157, and sY158 (AZFc). The ZFX gene on the X chromosome was used as an internal control to confirm PCR amplification. For each patient, 4 sets of multiplex PCR reactions were carried out including an internal control. Genomic DNA samples of a fertile man and a normal female were used as positive and negative controls, respectively. The PCR products were separated on a $3 \%$ agarose gel, stained with ethidium bromide and visualized using an ultraviolet illuminator.

\section{Semen, Hormonal and Testicular Analysis}

Semen analysis was performed twice in 18 patients according to the guidelines of the World Health Organization [World Health Organization, 1999]. Six fertile men with babies or whose partners had experienced abortion, 1 man with mental retardation and 1 woman were excluded. Testicular volume was evaluated using an orchidometer. Serum concentrations of follicle-stimulating hormone (FSH), luteinizing hormone (LH), testosterone, prolactin and estradiol were measured using electrochemiluminescence immunoassay and radioimmunoassay, according to the manufacturer's instructions. The histological examination of the testicular tissue revealed spermatogenic arrest in meiosis, confirming the diagnosis of non-obstructive azoospermia. Testicular histology was carried out in 11 patients.

Statistical Analysis

Statistical analysis was carried out by the Statistical Package for Social Science for Windows, version 11.0 (SPSS; Chicago, Ill., USA). Pearson correlation coefficients were used to determine correlations among sperm parameters, hormones and microdeletion of $A Z F$ genes. A p value $<0.05$ was considered significantly different.

\section{Results}

The karyotype, special banding, FISH, serum hormones, $A Z F$ deletion, semen parameters and testicular histology of the 26 patients with structural Y chromosome abnormalities are summarized in table 1. 
Table 1. A Summary of 26 patients with structural Y chromosome aberrations (part 1)

\begin{tabular}{|c|c|c|c|c|c|c|c|c|c|c|c|}
\hline \multirow{2}{*}{$\begin{array}{l}\text { Case } \\
\text { no. }\end{array}$} & \multirow[t]{2}{*}{ Age } & \multirow[t]{2}{*}{ Karyotype } & \multirow[t]{2}{*}{ Phenotype/fertility history } & \multicolumn{3}{|c|}{ Semen parameters } & \multicolumn{5}{|c|}{ Serum hormones } \\
\hline & & & & $\begin{array}{l}\text { volume } \\
\mathrm{ml}\end{array}$ & $\mathrm{pH}$ & $\begin{array}{l}\mathrm{N} / \mathrm{ml} \\
\mathrm{n} \times 10^{6}\end{array}$ & $\begin{array}{l}\mathrm{FSH} \\
\mathrm{mIU} / \mathrm{ml}\end{array}$ & $\begin{array}{l}\mathrm{LH} \\
\mathrm{mIU} / \mathrm{ml}\end{array}$ & $\begin{array}{l}\text { testosterone } \\
\mathrm{ng} / \mathrm{ml}\end{array}$ & $\begin{array}{l}\text { prolactin } \\
\mathrm{ng} / \mathrm{ml}\end{array}$ & $\begin{array}{l}\text { estradiol } \\
\mathrm{pg} / \mathrm{ml}\end{array}$ \\
\hline 1 & 31 & $46, \mathrm{X}, \mathrm{t}(\mathrm{Y} ; 7)(\mathrm{q} 11.222 ; \mathrm{p} 15.3)$ & $\mathrm{AZ}$ & 4.0 & 7.6 & 0 & 3.7 & 3.5 & 4.2 & 6.5 & - \\
\hline 2 & 36 & $46, \mathrm{X}, \mathrm{t}(\mathrm{Y} ; 17)(\mathrm{q} 11.221 ; \mathrm{p} 11.1)$ & $\mathrm{AZ}$ & 3.1 & 7.4 & 0 & 9.6 & 5.9 & 5.3 & 5.0 & 17.0 \\
\hline 3 & 36 & $46, \mathrm{X}, \mathrm{t}(\mathrm{Y} ; 22)(\mathrm{p} 11.2 ; \mathrm{q} 13.32)$ & $\mathrm{AZ}$ & 2.0 & 7.0 & 0 & 9.7 & 1.0 & 1.9 & - & 4.2 \\
\hline 4 & 47 & $46, \mathrm{X}, \operatorname{inv}(\mathrm{Y})(\mathrm{p} 11.2 \mathrm{q} 11.23)$ & $\mathrm{AZ}$ & 1.7 & 7.4 & 0 & 23.0 & 2.9 & 3.3 & 6.0 & 6.6 \\
\hline 5 & 40 & $46, \mathrm{X}, \operatorname{inv}(\mathrm{Y})(\mathrm{p} 11.2 \mathrm{q} 11.23)$ & $\begin{array}{l}\text { FM/G1 (AF;46,X,inv(Y) } \\
(\mathrm{p} 11.2 \mathrm{q} 11.23))\end{array}$ & - & - & - & - & - & - & - & - \\
\hline 6 & 39 & 46,X,inv(Y)(p11.2q11.23) & $\begin{array}{l}\text { FM/G2 P2 (2nd;46,X,inv(Y) } \\
(\mathrm{p} 11.2 \mathrm{q} 11.23))\end{array}$ & - & - & - & - & - & - & - & - \\
\hline 7 & 44 & $46, \mathrm{X}, \operatorname{inv}(\mathrm{Y})(\mathrm{p} 11.2 \mathrm{q} 11.23)$ & $\begin{array}{l}\text { FM/G1 P1 (46,X,inv(Y) } \\
(\mathrm{p} 11.2 \mathrm{q} 11.23))\end{array}$ & - & - & - & - & - & - & - & - \\
\hline 8 & 42 & $46, \mathrm{X}, \operatorname{inv}(\mathrm{Y})(\mathrm{q} 11.222 \mathrm{q} 12)$ & FM/G4 SA4 & - & - & - & - & - & - & - & - \\
\hline 9 & 34 & $46, \mathrm{X}, \operatorname{inv}(\mathrm{Y})(\mathrm{p} 11.2 \mathrm{q} 11.23) \mathrm{t}(8 ; 9)(\mathrm{q} 24.23 ; \mathrm{q} 33.2)$ & FM/G2 SA2 & 0.6 & 7.4 & 130 & - & - & - & - & - \\
\hline 10 & 28 & $45, \mathrm{X}, \operatorname{inv}(\mathrm{Y})(\mathrm{p} 11.2 \mathrm{q} 11.23), \operatorname{der}(13 ; 14)(\mathrm{q} 10 ; \mathrm{q} 10)$ & FM & 1.4 & 7.4 & 123 & - & - & - & - & - \\
\hline 11 & 29 & $46, \mathrm{X}, \operatorname{der}(\mathrm{Y})($ pter $\rightarrow \mathrm{q} 11.23:: \mathrm{p} 11.2 \rightarrow$ pter $)$ & $\mathrm{AZ}$ & 3.2 & 7.4 & 0 & 6.1 & 6.9 & 4.7 & 14.2 & 31.8 \\
\hline 12 & 23 & 46,X,der(Y)(pter $\rightarrow$ q11.23::p11.2 $\rightarrow$ pter $)$ & $\mathrm{AZ}$ & 4.0 & 7.2 & 0 & 17.0 & 5.2 & 2.3 & 11.0 & 18.0 \\
\hline 13 & 35 & $46, \mathrm{X}, \operatorname{del}(\mathrm{Y})(\mathrm{q} 11.23)$ & $\mathrm{AZ}$ & 2.2 & 7.4 & 0 & 30.0 & 5.3 & 3.3 & 3.0 & 16.0 \\
\hline 14 & 35 & 46,X,idic(Y)(q11.2) & $\mathrm{AZ}$ & 0.7 & 7.6 & 0 & 13.0 & 4.6 & 2.6 & 4.6 & 6.7 \\
\hline 15 & 38 & 46,X,idic(Y)(q11.21) & $\mathrm{AZ}$ & 0.1 & 7.0 & 0 & $<0.5$ & $<0.5$ & 5.3 & 4.5 & 39.0 \\
\hline 16 & 30 & 46,X,idic(Y)(q11.222) & $\mathrm{AZ}$ & 3.1 & 7.4 & 0 & 28.2 & 15.1 & 4.9 & 15.3 & 28.6 \\
\hline 17 & 29 & 46,X,idic(Y)(q11.2) & $\mathrm{AZ}$ & 2.2 & 7.6 & 0 & 3.0 & 8.5 & 2.8 & 6.1 & 12.0 \\
\hline 18 & 34 & 46,X,idic(Y)(q12) & $\mathrm{AZ}$ & 3.0 & 7.2 & 0 & 18.0 & - & 2.6 & - & 29.0 \\
\hline 19 & 35 & $45, \mathrm{X}[15] / 46, \mathrm{X}, \operatorname{idic}(\mathrm{Y})(\mathrm{q} 11.2)[85]$ & $\mathrm{AZ}$ & 4.6 & 7.2 & 0 & 10.0 & 4.6 & 3.1 & 14.0 & 16.0 \\
\hline 20 & 36 & $45, \mathrm{X}[14] / 46, \mathrm{X}, \mathrm{idic}(\mathrm{Y})(\mathrm{q} 11.222)[95]$ & $\mathrm{AZ}$ & 3.0 & 7.4 & 0 & 28.0 & 11.0 & 1.8 & 6.1 & 9.8 \\
\hline 21 & 41 & $45, \mathrm{X}[4] / 46, \mathrm{X}, \operatorname{idic}(\mathrm{Y})(\mathrm{q} 11.222)[113]$ & $\mathrm{AZ}$ & 0.9 & 7.6 & 0 & 48.0 & 6.7 & 4.7 & 5.2 & 5.8 \\
\hline 22 & 30 & $46, \mathrm{X}, \mathrm{idic}(\mathrm{Y})(\mathrm{q} 11.23)[58] / 46, \mathrm{i}(\mathrm{Y})(\mathrm{p} 10)[45]$ & $\mathrm{AZ}$ & 1.6 & 8.0 & 0 & 22.0 & 3.2 & 5.5 & 8.1 & 12.0 \\
\hline 23 & 34 & $45, \mathrm{X}[93] / 47, \mathrm{X}, \operatorname{idic}(\mathrm{Y})(\mathrm{q} 11.23), \operatorname{idic}(\mathrm{Y})[13]$ & male (without semen analysis) & - & - & - & 26.0 & 6.8 & 0.7 & 7.2 & 7.2 \\
\hline 24 & 27 & 45,X[29]/46,X,idic(Y)(q11.23)[84] & female & - & - & - & 130.0 & 13.0 & 0.2 & 8.4 & 8.2 \\
\hline 25 & 38 & 46,X,Yqs & FM/G1 (AF;46,X,Yqs) & - & - & - & - & - & - & - & - \\
\hline 26 & 36 & 46,X,Yqs & FM/G2 L:0 D:1 (AF;46,X,Yqs) & - & - & - & - & - & - & - & - \\
\hline
\end{tabular}

$\mathrm{AF}=$ Amniotic fluid; $\mathrm{AZ}=$ azoospermic male; $\mathrm{D}=$ death; $\mathrm{FM}=$ fertile male; $\mathrm{FSH}=$ follicle-stimulating hormone; $\mathrm{G}=\mathrm{gravida} ; \mathrm{L}=$ live; $\mathrm{LH}=$ luteinizing hormone; $\mathrm{P}=$ para; $\mathrm{SA}=$ spontaneous abortion.

Normal reference ranges for men: FSH $=1.5-12.4 \mathrm{mIU} / \mathrm{ml}, \mathrm{LH}=1.7-8.6 \mathrm{mIU} / \mathrm{ml}$, testosterone $=1.31-8.13 \mathrm{ng} / \mathrm{ml}$, prolactin $=4.04-15.2 \mathrm{ng} / \mathrm{ml}$, estradiol $=7.4-80.0 \mathrm{pg} / \mathrm{ml}$; and for women: $\mathrm{FSH}=2-12 \mathrm{mIU} / \mathrm{ml}, \mathrm{LH}=1.8-13.4 \mathrm{mIU} / \mathrm{ml}$, testosterone $=0.06-0.77 \mathrm{ng} / \mathrm{ml}, \mathrm{prolactin}=2.7-19.7 \mathrm{ng} / \mathrm{ml}$, estra$\mathrm{diol}=30-120 \mathrm{pg} / \mathrm{ml}$.

\section{Translocation of Y Chromosome; $t$ (Y;autosome)}

Reciprocal balanced Y chromosome translocations were found in 3 patients with karyotypes of $t(Y ; 7), t(Y ; 17)$ and $t(Y ; 22)$, respectively. For the patient with $t(Y ; 22)$, Gbanding chromosomes and ideograms are shown as well as FISH using SRY/CEP X (fig. 1B). Additionally, TelVysion $22 \mathrm{q}$ probes confirmed the presence of a $22 \mathrm{q}$ terminal region on the derivative Y chromosome and an SRY region on the end of the derivative 22 chromosome (not shown). Serum hormone levels of FSH, LH, testosterone, prolactin and estradiol were normal in the translocation patients, but the estradiol level in case 3 was slightly decreased (4.2 pg/ml; normal range, 7.4-80 pg/ml). Molecular studies revealed that 3 patients had intact $S R Y$ genes with an absence of AZFabc deletions. Spermiograms of the 3 patients showed azoospermia.

\section{Inversions on $Y$ Chromosome; $i n v(Y)$}

$\operatorname{Inv}(\mathrm{Y})$ was found in 7 patients. Six of them had a pericentric inv $(\mathrm{Y})$ with breakpoints on the short (p11.2) and long arms (q11.23). One patient had a paracentric inv $(\mathrm{Y})$ with breakpoints on Yq11.222 and Yq12. And, CBG-/DADAPI-banding revealed a partially inverted heterochromatin, and FISH with a DYZ1 probe confirmed 2 signals on the paracentric inv(Y) (fig. 1C). Molecular studies showed that 6 patients had the SRY gene and no AZFabc deletions. But 1 patient (case 9) had 2 microdeletions of sY130 on the AZFb and sY147 on the AZFc. Six patients including case 9 were healthy and fertile men. However, case 4 showed azoospermia and was treated with testicular sperm extraction. The result of intracytoplasmic sperm injection (ICSI) was not good because of poor sperm quality. The patient showed normal levels of hor- 
Table 1. B (part 2)

\begin{tabular}{|c|c|c|c|c|c|c|c|c|c|c|c|c|c|c|c|c|c|c|c|c|c|}
\hline \multirow[t]{3}{*}{$\begin{array}{l}\text { Case } \\
\text { No. }\end{array}$} & \multicolumn{16}{|c|}{ Microdeletion analysis } & \multicolumn{2}{|c|}{$\begin{array}{l}\text { Testis volume } \\
\mathrm{ml}\end{array}$} & \multirow[t]{3}{*}{ TESE } & \multirow[t]{3}{*}{ ISCI } & \multirow[t]{3}{*}{$\begin{array}{l}\text { Testicular histology or physical } \\
\text { examination }\end{array}$} \\
\hline & \multirow[t]{2}{*}{ ZFX } & \multirow{2}{*}{$\begin{array}{l}\text { SRY } \\
\text { sY } \\
14\end{array}$} & \multicolumn{2}{|c|}{$\mathrm{AZFa}$} & \multicolumn{5}{|c|}{$\mathrm{AZFb}$} & \multicolumn{7}{|c|}{ AZFc } & \multirow[t]{2}{*}{ right } & \multirow[t]{2}{*}{ left } & & & \\
\hline & & & $\begin{array}{l}\text { sY } \\
84\end{array}$ & $\begin{array}{l}\text { sY } \\
86\end{array}$ & $\begin{array}{l}\text { sY } \\
124\end{array}$ & $\begin{array}{l}\text { sY } \\
127\end{array}$ & $\begin{array}{l}\text { sY } \\
129\end{array}$ & $\begin{array}{l}\text { sY } \\
130\end{array}$ & $\begin{array}{l}\text { sY } \\
134\end{array}$ & $\begin{array}{l}\text { sY } \\
147\end{array}$ & $\begin{array}{l}\text { sY } \\
242\end{array}$ & $\begin{array}{l}\text { sY } \\
254\end{array}$ & $\begin{array}{l}\text { sY } \\
255\end{array}$ & SPGY1 & $\begin{array}{l}\text { sY } \\
157\end{array}$ & $\begin{array}{l}\text { sY } \\
158\end{array}$ & & & & & \\
\hline 1 & + & + & + & + & + & + & + & + & + & + & + & + & + & + & + & + & 18 & 18 & & & MA \\
\hline 2 & + & + & + & + & + & + & + & + & + & + & + & + & + & + & + & + & 13 & 13 & & & MA \\
\hline 3 & + & + & + & + & + & + & + & + & + & + & + & + & + & + & + & + & 17 & 17 & & & HS \\
\hline 4 & + & + & + & + & + & + & + & + & + & + & + & + & + & + & + & + & 10 & 10 & yes & yes & MA \\
\hline 5 & + & + & + & + & + & + & + & + & + & + & + & + & + & + & + & + & & & & & \\
\hline 6 & + & + & + & + & + & + & + & + & + & + & + & + & + & + & + & + & & & & & \\
\hline 7 & + & + & + & + & + & + & + & + & + & + & + & + & + & + & + & + & & & & & \\
\hline 8 & + & + & + & + & + & + & + & + & + & + & + & + & + & + & + & + & & & & & \\
\hline 9 & + & + & + & + & + & + & + & - & + & - & + & + & + & + & + & + & & & & & \\
\hline 10 & + & + & + & + & + & + & + & + & + & + & + & + & + & + & + & + & 17 & 17 & & & NM \\
\hline 11 & + & + & + & + & + & + & + & + & + & + & + & + & + & + & + & + & 15 & 15 & yes & & HS \\
\hline 12 & + & + & + & + & + & + & + & + & + & + & + & + & + & + & + & + & 0 & 8 & & & \\
\hline 13 & + & + & + & + & + & + & + & + & + & - & - & - & - & - & - & - & 15 & 15 & & & SCOS \\
\hline 14 & + & + & + & + & - & - & - & - & - & - & - & - & - & - & - & - & 11 & 11 & & & MA, tubular hyalinization \\
\hline 15 & + & + & - & - & - & - & - & - & - & - & - & - & - & - & - & - & 5 & 5 & & & \\
\hline 16 & + & + & + & + & - & - & - & - & - & - & - & - & - & - & - & - & 12 & 12 & & & \\
\hline 17 & + & + & + & - & - & - & - & - & - & - & - & - & - & - & - & - & 2 & 2 & yes & & \\
\hline 18 & + & + & + & + & + & + & + & + & + & + & + & + & + & + & + & + & 3 & 3 & & & MA, tubular hyalinization \\
\hline 19 & + & + & + & + & + & + & + & + & + & + & + & + & + & + & + & + & 13 & 13 & & & normal spermatogensis \\
\hline 20 & + & + & + & + & - & - & - & - & - & - & - & - & - & - & - & - & 8 & 8 & & & \\
\hline 21 & + & + & + & + & - & - & - & - & - & - & - & - & - & - & - & - & 5 & 5 & & & MA \\
\hline 22 & + & + & + & + & + & + & + & + & + & - & - & - & - & - & - & - & 15 & 15 & & & scos \\
\hline 23 & + & + & + & + & + & - & - & - & - & - & - & - & - & - & - & - & 4 & 4 & & & mental retardation, $\mathrm{NM}$ \\
\hline 24 & + & + & + & + & + & + & + & + & + & + & + & + & + & + & + & + & & & & & primary amenorrhea, short height \\
\hline 25 & + & + & + & + & + & + & + & + & + & + & + & + & + & + & + & + & & & & & \\
\hline 26 & + & + & + & + & + & + & + & + & + & + & + & + & + & + & + & + & & & & & \\
\hline
\end{tabular}

HS = Hypospermatogenesis; ICSI = intracytoplasmic sperm injection; MA = maturation arrest; NM = not married; SCOS = Sertoli cell only syndrome; TESE = testicular sperm extraction. For better visibility, deletions are highlighted in grey.

mone except for an elevation in FSH level $(23 \mathrm{mIU} / \mathrm{ml}$; normal range, $1.5-12.4 \mathrm{mIU} / \mathrm{ml}$ ).

\section{Derivative Y Chromosome; $\operatorname{der}(Y)$}

A rearranged monocentric $\operatorname{der}(\mathrm{Y})$ was found in 2 patients, and their karyotypes were $46, \mathrm{X}, \operatorname{der}(\mathrm{Y})$ (pter $\rightarrow$ q11.23::p11.2 $\rightarrow$ pter). These patients lacked the heterochromatic Yq12 region according to CBG- and DADAPI-banding. FISH using an SRY-specific probe indicated a double copy of the $S R Y$ gene, shown with a centromeric probe for the $\mathrm{X}$ chromosome as a control. FISH with the Y alpha satellite (DYZ3)/Y satellite III (DYZ1) probes confirmed the presence of 1 centromere copy, and a Y heterochromatin probe showed no signal on the rearranged Y chromosome (fig. 1D). Serum hormone levels in the 2 patients were within the normal range. The results of the deletion analysis of the AZF region showed all 14 loci to be present (fig. 2). These 2 patients were azoospermic men.

\section{Deletion on the Y Chromosome; $\operatorname{del}(Y)$}

$\operatorname{Del}(\mathrm{Y})$ was observed in 1 patient with a breakpoint at q11.23 (fig. 1E). DA-DAPI-banding revealed that the $\operatorname{del}(\mathrm{Y})$ was lacking the heterochromatic Yq12 region. The diagnostic screening of the AZF region showed that 8 loci in the AZFc region were deleted. FSH concentration was elevated ( $30 \mathrm{mlU} / \mathrm{ml}$; normal range, $1.5-12.4 \mathrm{mlU} / \mathrm{ml}$ ), but LH, testosterone, and estradiol were within the normal range. Prolactin was slightly diminished. The semen analysis results showed azoospermia.

\section{Isodicentric Y Chromosome; idic( $Y)$}

$\operatorname{Idic}(\mathrm{Y})$ was found in 11 patients: 5 men with non-mosaic idic(Y) with a breakpoint on Yq, 4 men and 1 woman with a mosaic karyotype having a 45,X cell line, and 1 man with a mosaic of 2 cell-lines with a breakpoint on Yq and centromere. FISH analysis and CBG-banding revealed the presence of 2 copies of the SRY gene and cen- 

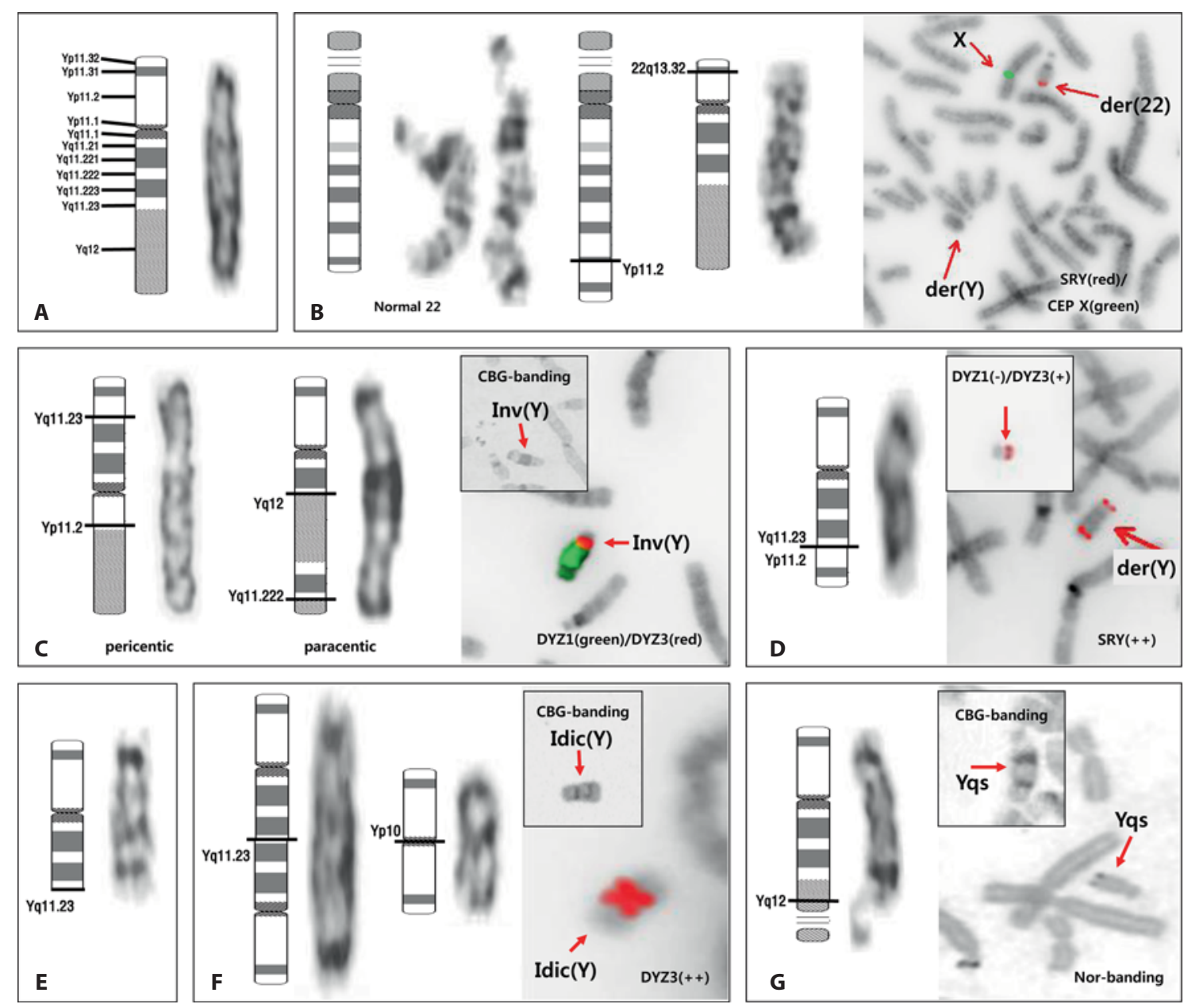

Fig. 1. Partial ideograms, GTL-banding karyotypes, special banding and FISH showing structural abnormalities of the Y chromosome. A Normal Y chromosome. B Translocation (case 3). C Pericentric (case 4) and paracentric (case 8) inversions. D Derivative chromosome (case 11). E Deletion (case 13). F Mosaic with isodicentric and isochromosome (case 22). G Satellited Y chromosome (case 25).

tromeric region but no constitutive heterochromatic characteristics on the idic(Y) (fig. 1F). FSH hormonal level was slightly increased in 7 male patients, extremely decreased in 1 male patient (case $15,<0.5 \mathrm{mIU} / \mathrm{ml}$ ) and extremely increased in 1 female patient (case 24). The LH level was slightly increased in 2 men and extremely decreased in 1 male patient (case $15,<0.5 \mathrm{mIU} / \mathrm{ml}$ ). Estradiol was slightly decreased in 3 male patients and extremely decreased in 1 female patient. Testosterone level was decreased in 1 male (case 23) and prolactin levels were normal in all patients.

Eight male patients had AZF deletions: 2 had AZFabc deletions, 5 had AZFbc deletions (fig. 2) and 1 had an AZFc deletion. Two azoospermic males and 1 female had no AZF deletions. Semen analysis of 9 male patients re- vealed that all had azoospermia. The female patient was referred at the age of 27 years because of primary amenorrhea, with a height of $146 \mathrm{~cm}$, and ultrasound evaluation showed the absence of uterus findings and abnormal shape of both ovaries.

\section{Satellited Y Chromosome; Yqs}

Yqs was observed in 2 patients who were recommended for analysis based on amniotic cell analysis results of 46,XYqs. In 2 families, CBG- and DA-DAPI-staining showed the presence of constitutive heterochromatin, and silver staining demonstrated active NORs within the satellited stalks of the Y chromosome (fig. 1G). Molecular analysis of the AZF region did not reveal any deletions in the 2 patients. 
Fig. 2. Representative gel electrophoresis profiles of 2 patients. A Multiplex PCR of ZFX, SRY (sY14), sY254, sY86 and sY127. B $Z F X, s Y 14$, sY134 and sY225. C ZFX, SPGY1, sY158, sY129 and sY147. D ZFX, sY84, sY157, sY242, sY130 and sY124. Patient 1 with idic(Y) (P1: case 16) had $\mathrm{AZFb}$ (sY124, 127, 129, 130 and 134) and AZFc (sY147, 242, 255, 157,158 and SPGY1) deletions, whereas patient 2 with $\operatorname{der}(\mathrm{Y})(\mathrm{P} 2$ : case 11) had no deletion. In addition, the genomic DNA from 1 fertile male $(\mathrm{M})$, normal female (F) and distilled water without gDNA (W) were also included as positive and negative controls, respectively. The arrows denote the deletions in the particular sequence-tagged site region.
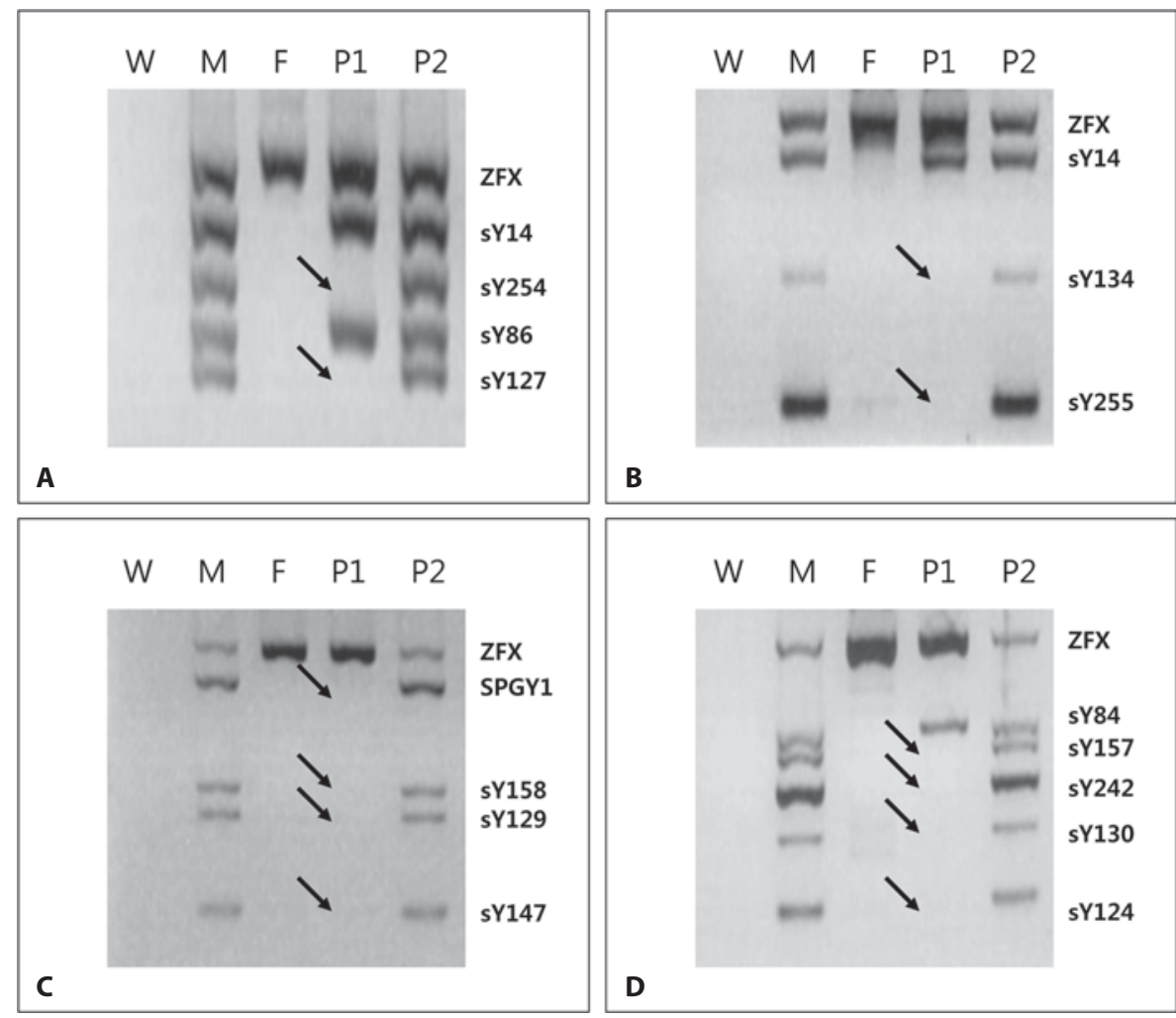

\section{Deletions of the AZF Region}

Deletions of the AZF region were detected in 8 of 16 azoospermia patients (50\%): AZFabc region (2 cases), AZFbc (4 cases) and AZFc (2 cases). Deletions of the $\mathrm{AZFb}$ region were correlated with the sperm concentration $(\mathrm{p}<0.05)$, but no correlation with the levels of FSH, $\mathrm{LH}$, testosterone, prolactin and estradiol could be detected.

\section{Discussion}

Balanced translocations between the $\mathrm{Y}$ and autosomal chromosomes occur with a frequency of $1 / 2,000$ in the general population [Nielsen and Rasmussen, 1976; Powell, 1999]. They do not usually have any phenotypic consequences but often lead to azoospermia, a variety of male gamete abnormalities and infertility depending on the breakpoint [Hsu, 1994; Pinton et al., 2008]. On the other hand, unbalanced Y;autosomal translocations have been reported in children with malformations and/or sexual ambiguity [Mademont-Soler et al., 2009]. In our study, there were 3 patients with confirmed balanced translocations and azoospermia without AZF microdeletion.
Inversions occur when there are 2 breaks in a single chromosome. If 1 break occurs in the short arm and the other in the long arm of the chromosome, this is called a pericentric inversion. If both breaks occur in the same arm of the chromosome, this is called a paracentric inversion. The frequency of pericentric $\operatorname{inv}(\mathrm{Y})$ ranges from 0.07 to $5.7 \%$ in the general population, and most of the reported cases are familial [Wyandt and Tonk, 2004]. Pericentric $\operatorname{inv}(\mathrm{Y})$ is not considered to be associated with any phenotypic manifestations or fertility problems. In some rare cases, reduced fertility or phenotypic abnormalities related to sex determination are associated with deletion or disruption of genes located in the inverted area [Gimelli et al., 2006]. Paracentric inv(Yq) is very rare and generally harmless [Madan, 1995; Aiello et al., 2007]. However, a patient with a familial paracentric inv(Yq) and ambiguous genitalia has been reported [Liou et al., 1997]. Among the cases in our study, there were 6 pericentric and 1 paracentric inv(Y). One patient with pericentric inv $(\mathrm{Y})$ and no AZF deletions had azoospermia, but the other males were healthy and fertile.

A derivative chromosome is a structurally rearranged chromosome generated either by a rearrangement involving 2 or more chromosomes or by multiple aberra- 
tions within a single chromosome. $\operatorname{Der}(\mathrm{Y})$ is a possible mechanism for sister-chromatid rearrangement during paternal meiosis or in the very early stages of embryogenesis [Cui et al., 2009]. To our knowledge, $\operatorname{der}(\mathrm{Y})$ has rarely been reported. In this study, we identified $\operatorname{der}(\mathrm{Y})$ in 2 azoospermic males as a segmental duplication of Ypter-p11.2 and a deletion of q11.23-qter by cytogenetic and FISH analysis, without any deletion in the AZF region.

Deletion may be caused by loss of a part of a chromosome between 1 or 2 breakpoints, and loss of a tiny fragment may have no noticeable effect. However, a deletion of a chromosome has a major effect that varies according to the chromosome affected, the site of and the extent of the deletion. Del(Yq) has been identified by cytogenetic analysis in around 3\% of infertile men having abnormal Y chromosome [Gekas et al., 2001]. It is generally accepted that $\operatorname{del}(\mathrm{Y})(\mathrm{q} 12)$ is not associated with infertility because the deletion is limited to the heterochromatin, whereas $\operatorname{del}(\mathrm{Y})(\mathrm{q} 11)$ is associated with azoospermia or severe oligospermia due to the involvement of the AZF region [Delobel et al., 1998]. Here, we report a case of azoospermia with karyotype $\operatorname{del}(\mathrm{Y})(\mathrm{q} 11.23)$ and AZFc deletion.

Dicentric Y chromosomes correspond to 2 different types: $\operatorname{dic}(\mathrm{Yq})$ resulting from the fusion between the short arms of $2 \mathrm{Y}$ chromosomes in which some Yp material is maintained and $\operatorname{dic}(\mathrm{Yp})$ in which only the Yq arms fuse. If the dicentric has completely symmetric arms, it is considered an isodicentric chromosome [Robinson et al., 1999]. Idic(Y) is the most common aberration, occurring in $15 \%-30 \%$ of infertile men having an abnormal $Y$ chromosome [Codina-Pascual et al., 2004]. Because of its meiotic or post-zygotic origin and its mitotic instability, most (90\%) $\operatorname{idic}(\mathrm{Y})$ chromosomes are present in mosaicism with a $45, \mathrm{X}$ cell line. Depending on the breakpoints and the types of mosaicism, patients with idic $(Y)$ have a wide range of phenotypic manifestations [Tuck-Muller et al., 1995; Iourov et al., 2008]. As previously reviewed, 40.9\% of affected individuals were phenotypic females, $31.8 \%$ were phenotypic males and $27.3 \%$ had different degrees of intersexuality [Hsu, 1994]. In the present study, we analyzed 11 isodicentric Y chromosomes with $\operatorname{dic}(\mathrm{Yp})$ type, and 6 of these cases (54.5\%) had mosaicism. Affected persons included 1 phenotypic woman, 9 men with azoospermia and 1 man without semen analysis because of mental retardation. Eight patients (72.7\%) had a deletion of the AZF region.

Yqs is the product of a translocation between part of the NOR-bearing short arm of an acrocentric autosome and the Y heterochromatin band, Yq12. Yqs was first described by Genest et al. [1967] and belongs to the category of very rare chromosomal abnormalities. In all except 2 de novo cases, the Yqs chromosome has been shown to be an inherited variant without any clinical consequences [Yakut et al., 2011]. The satellites are derived from acrocentric chromosomes mostly from chromosome 15 or, less frequently, from chromosomes 21,13 or 14 [Schmid et al., 1984]. In this study, we reported 2 familial cases without any deletion of the AZF region.

Male infertility can be caused by a variety of factors, such as infection, varicose, endocrine disorders, etc. Apart from these, Yq deletions are the most frequent genetic cause of male infertility. A particular area of interest on $\mathrm{Yq}$ is the AZF region, which contains genes involved in the growth and development of sperm. These AZF genes code for RNA binding proteins and might be involved in regulation of gene expression, RNA metabolism, packaging and transport to cytoplasm and RNA splicing [Zamani et al., 2006]. The detection of Yq deletions is very important since this chromosome defect can be transmitted to $100 \%$ of the male offspring. However, the clinical significance of Yq deletions has been debated for a long time, mainly because of the large variation in deletion frequencies reported by different authors and because Yq deletions have also been reported in fertile men. We found 8 deletions in 16 azoospermic patients, and deletions of the $\mathrm{AZFbc}$ region were correlated with the sperm concentration $(\mathrm{p}<0.05)$.

Structural chromosomal anomalies are related to the increased risk of aneuploidy or unbalanced chromosomal complements and carry a poor prospect of sperm retrieval [Krausz et al., 2000]. Artificial reproduction techniques, such as preimplantation genetic diagnosis, ICSI and testicular sperm extraction, can help couples to achieve genetic parenthood. We carried out testicular sperm extraction in 3 men with azoospermia and conducted ICSI in 1 man. Unfortunately, our reports showed a poor result of ICSI in a non-obstructive azoospermic case. However, it is imperative to analyze the accurate identification and characterization of $\mathrm{Y}$ chromosome structural alterations for genetic counseling and clinical decisions regarding the optimal artificial reproduction technique treatment.

In conclusion, structural Y chromosome abnormalities are associated with human infertility, and deletions in the AZFbc region are associated with low sperm concentration due to reduced spermatogenesis. 


\section{References}

-Aiello V, Astolfi N, Gruppioni R, Buldrini B, Prontera $\mathrm{P}$, et al: Paracentric inversion of $\mathrm{Yq}$ and review of the literature. Genet Couns 18: 379-382 (2007).

-Arnemann J, Schnittger S, Hinkel GK, Tolkendorf E, Schmidtke J, Hansmann I: A sterile male with 45,X0 and a Y;22 translocation. Hum Genet 87:134-138 (1991).

-Codina-Pascual M, Oliver-Bonet M, Navarro J, Starke H, Liehr T, et al: FISH characterization of a dicentric Yq (p11.32) isochromosome in an azoospermic male. Am J Med Genet A 127:302-306 (2004).

-Cui YX, Shi YC, Liu Q, Xia XY, Lu HY, et al: A case of agonadism associated with Ychromosome rearrangement: cytogenetic and molecular studies. J Androl 30:650-654 (2009).

-Delobel B, Djlelati R, Gabriel-Robez O, Croquette MF, Rousseaux-Prevost R, et al: Y-autosome translocation and infertility: usefulness of molecular, cytogenetic and meiotic studies. Hum Genet 102:98-102 (1998).

-DesGroseilliers M, Fortin F, Lafreniere AM, Brochu P, Lemyre E, Lemieux N: Dynamic increase of a $45, X$ cell line in a patient with multicentric ring $\mathrm{Y}$ chromosomes. Cytogenet Genome Res 115:90-93 (2006).

-Disteche CM, Brown L, Saal H, Friedman C, Thuline HC, et al: Molecular detection of a translocation $(\mathrm{Y} ; 15)$ in a $45, \mathrm{X}$ male. Hum Genet 74:372-377 (1986).

Gardner RJ, Sutherland GR: Chromosome Abnormalities and Genetic Counseling. Sex chromosome translocations, pp 95-114 (Oxford University Press, Oxford 1996).

-Gekas J, Thepot F, Turleau C, Siffroi JP, Dadoune JP, et al: Chromosomal factors of infertility in candidate couples for ICSI: an equal risk of constitutional aberrations in women and men. Hum Reprod 16:82-90 (2001).

Genest P, Bouchard M, Bouchard J: A satellited human Y chromosome: an evidence of autosome gonosome translocation. Can J Genet Cytol 9:589-595 (1967).
Gimelli G, Giorda R, Beri S, Gimelli S, Zuffardi OA: 46,X,inv $(\mathrm{Y})$ young woman with gonadal dysgenesis and gonadoblastoma: cytogenetics, molecular, and methylation studies. Am J Med Genet A 140:40-45 (2006).

Hsu LY: Phenotype/karyotype correlations of Y chromosome aneuploidy with emphasis on structural aberrations in postnatally diagnosed cases. Am J Med Genet 53:108-140 (1994).

Iourov IY, Vorsanova SG, Liehr T, Monakhov VV, Soloviev IV, Yurov YB: Dynamic mosaicism manifesting as loss, gain and rearrangement of an isodicentric $\mathrm{Y}$ chromosome in a male child with growth retardation and abnormal external genitalia. Cytogenet Genome Res 121:302-306 (2008).

ISCN 2005: An International System for Cytogenetic Nomenclature (S. Karger, Basel 2005).

ISCN 2009: An International System for Human Cytogenetic Nomenclature (S. Karger, Basel 2009).

Krausz C, Quintana-Murci L, McElreavey K: Prognostic value of $Y$ deletion analysis: what is the clinical prognostic value of Y chromosome microdeletion analysis? Hum Reprod 15:1431-1434 (2000).

- Lin YH, Chuang L, Lin YM, Lin YH, Teng YN, Kuo PL: Isochromosome of Yp in a man with Sertoli-cell-only syndrome. Fertil Steril 83: 764-766 (2005).

-Liou JD, Ma YY, Gibson LH, Su H, Charest N, et al: Cytogenetic and molecular studies of a familial paracentric inversion of $\mathrm{Y}$ chromosome present in a patient with ambiguous genitalia. Am J Med Genet 70:134-137 (1997).

Madan K: Paracentric inversions: a review. Hum Genet 96:503-515 (1995).

Mademont-Soler I, Morales C, Madrigal I, Margarit E, Bruguera J, et al: Prenatal diagnosis of two different unbalanced forms of an inherited (Y;12) translocation. Am J Med Genet A 149A:2820-2823 (2009).

Nielsen J, Rasmussen K: Y/autosomal translocations. Clin Genet 9:609-617 (1976).

Pinton A, Raymond Letron I, Berland HM, Bonnet N, Calgaro A, et al: Meiotic studies in an azoospermic boar carrying a Y;14 translocation. Cytogenet Genome Res 120:106-111. (2008).
Powell C: Sex chromosomes and sex abnormalities, in Gersen GL, Keagle MB (eds): The Principles of Clinical Cytogenetics, pp 229258 (Humana Press, Totowa, NJ 1999).

Robinson DO, Dalton P, Jacobs PA, Mosse K, Power MM, Crolla JA: A molecular and FISH analysis of structurally abnormal Y chromosomes in patients with Turner syndrome. J Med Genet 36:279-284 (1999).

-Schmid M, Haaf T, Solleder E, Schempp W, Leipoldt M, Heilbronner H: Satellited Y chromosomes: structure, origin, and clinical significance. Hum Genet 67:72-85 (1984).

- Sinclair AH, Berta P, Palmer MS, Hawkins JR, Griffiths BL, et al: A gene from the human sex-determining region encodes a protein with homology to a conserved DNA-binding motif. Nature 346:240-244 (1990).

-Skaletsky H, Kuroda-Kawaguchi T, Minx PJ, Cordum HS, Hillier L, et al: The male-specific region of the human $\mathrm{Y}$ chromosome is a mosaic of discrete sequence classes. Nature 423:825-837 (2003).

Tuck-Muller CM, Chen H, Martinez JE, Shen CC, Li S, et al: Isodicentric Y chromosome: cytogenetic, molecular and clinical studies and review of the literature. Hum Genet 96: 119-129 (1995).

Vogt PH, Edelmann A, Kirsch S, Henegariu O, Hirschmann P, et al: Human Y chromosome azoospermia factors (AZF) mapped to different subregions in Yq11. Hum Mol Genet 5: 933-943 (1996).

World Health Organization: WHO Laboratory Manual for the Examination of Human Semen and Semen-Cervical Mucus Interaction, 4th ed. (Cambridge University Press, Cambridge 1999).

Wyandt HE, Tonk VS: Atlas of Human Chromosome Heteromorphisms (Kluwer Academic Publishers, Dordrecht 2004).

- Yakut S, Ozturk S, Simsek M, Mendilcioglu II, Luleci G: The prenatal diagnosis of familial satellited Yq chromosomes. Turk J Med Sci 41:945-948 (2011).

Zamani AG, Kutlu R, Durakbasi-Dursun HG, Gorkemli H, Acar A: Y chromosome microdeletions in Turkish infertile men. Indian J Hum Genet 12:66-71 (2006). 